Yayınlayan: Ankara Üniversitesi KASAUM

Adres: Kadın Sorunları Araştırma ve Uygulama Merkezi, Cebeci 06590 Ankara

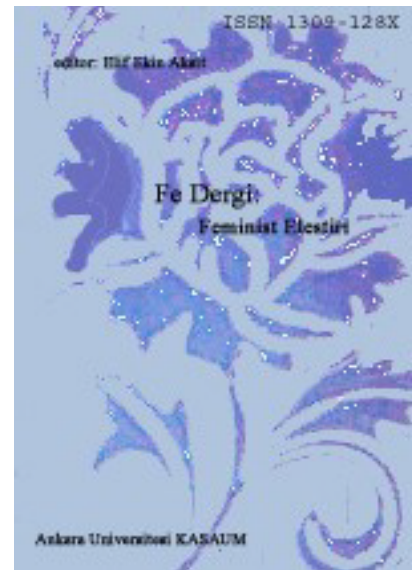

Fe Dergi: Feminist Eleştiri 4, Sayı 1

Erişim bilgileri, makale sunumu ve ayrıntılar için:

http://cins.ankara.edu.tr/

Seksoloji: 1945-1955 arası Türkiye'de cinsel terbiye

Ezgi Sarıtaş

Çevrimiçi yayına başlama tarihi: 25 Aralık 2012

Bu makaleyi alıntılamak için: Ezgi Sarıtaş, "Seksoloji: 1945-1955 arası Türkiye'de cinsel terbiye" Fe Dergi 4, say1 2 (2012), 57-71.

URL: http://cins.ankara.edu.tr/8_6.html

$\mathrm{Bu}$ eser akademik faaliyetlerde ve referans verilerek kullanılabilir. Hiçbir şekilde izin alınmaksızın çoğaltılamaz. 


\section{Seksoloji: 1945-1955 arası Türkiye'de cinsel terbiye Ezgi Sarıtaş*}

Bu yazıda 1949-1954 yılları arasında yayımlanmış Seksoloji: Cinsî Bilgiler Mecmuası'nı incelemeyi amaçlıyorum. Yapacağım incelemeyle, 1950lerin başında Türkiye'de cinselliğe dair söylemlerin 'cinsel terbiye' başlı̆̆ altında nasıl eklemlendiklerine ve geçerli kılındıklarına bakacă̆ım. Her ne kadar salt dergi üzerine yapacă̆ım inceleme dönemin cinsiyet rejimini anlamaya yetmeyecek olsa da, derginin içeriği dönemin toplumsal cinsiyet ilişkileri bă̆lamında dĕgerlendirildiğinde önem kazanmaktadır. Foucault'nun on dokuzuncu yüzyıl cinsel bilimi için sorduğu bir sorunun, bu yazının ele aldiğ meseleler açısından önemli olduğunu düşünüyorum: Cinselliğe ilişkin belirli dönemde ortaya çıkan söylemde ne gibi yerel iktidar bă̆ıntıları görebiliriz, bu bă̆ıntıların arasındaki ilişkiler nelerdir ve değişimlerini nasıl anlayabiliriz? Her ne kadar yazl, bu soruya cevaplama iddiasinda olmasa da, Seksoloji dergisini ve derginin yayımlandı̆̆ dönemde toplumsal cinsiyet ilişkilerini ele almak bu sorular ekseninde anlam kazanacaktır.

Anahtar sözcükler: cinsel terbiye, cinsellik bilimi, 1950lerde toplumsal cinsiyet rejimi

\section{Sexology: Sexual conduct in Turkey between 1945 and 1955}

In this article I want to analyze the Sexology: Sexual Knowledge Magazine published between the years 1949-1954. With this analysis, I want to look at the ways different discourses on sexuality are articulated and authorized under the title of 'sexual conduct'. Although an analysis that is focused exclusively on the magazine is not enough to understand the gender regime of the period in question, the content of the magazine will be analyzed within the framework of the gender relations of that period. A question posed by Foucault for the sexual science of nineteenth century is relevant to the issues dealt with in this article: Which power relations can be observed in a discourse on sexuality that emerged during a certain period and how can we understand these relations and their transformation? Even though the article does not claim to provide an answer to this question, the magazine and gender relations during the time of its publication will be framed with these questions.

Key words: sexual conduct, sexual science, gender regime in 1950 s

\section{Giriș: On dokuzuncu yüzyıl Avrupa'sında cinsellik bilimi}

Bu yazıda 1950'lerin ilk yarısında yayımlanan Seksoloji: Cinsî Bilgiler Mecmuası (bundan sonra Seksoloji) dergisi üzerine yapacağım incelemeyle, cinselliğin kurulumunda farklı söylemlerin eklemlenişi ve geçerli kılınışına bakacağım. Özellikle cinsel terbiye kavramına yoğunlaşarak farklı söylemsel eklemlenmelerin bu kavramı nasıl tanımladığına yoğunlaşacağım.

Seksoloji - cinsellik bilimi - bir bilim dalı olarak on dokuzuncu yüzyıl sonlarında Almanya'da, Aydınlanma'nın etkisiyle ortaya çıkan hukuki ve bilimsel özne kavrayışıyla yakından ilişkili biçimde ortaya çıkmıştır. ${ }^{1}$ Sosyoloji, antropoloji gibi sağlık, üreme ve insan cinselliğine odaklanan beşeri bilimlerin de çağdaşıdır. ${ }^{2}$ On dokuzuncu yüzyıl boyunca ilerleyen bu bilimlerin de etkisiyle cinsellik yalnızca kadın/erkek karşıtlığı üzerinden değil, normal/anormal, tabii/gayritabiî, sapkın/sağlıklı gibi karşıtlıklarla da tanımlanır hale gelmiştir. Batı düşüncesinin ikili düşünce sistemi, seksoloji söylemi içinde sürekli yeni karşıtlıklarla eklemlenerek kendini sürdürmüştür.

Seksoloji - scienta sexualis - Foucault'nun da söylediği gibi bilim-iktidar biçimine göre düzenlenen yöntemler geliştirmiştir. Erotik sanatla bağlarını koparan ve kilise söylemine endekslenen cinsel bilim, cinselliğe yönelik doğru söylemler oluşturma çabasında itirafı, bilimsellik kurallarına oturtmuştur. Hıristiyan Batı'da cinselliğe dair hakikat üretiminin ilk yöntemi olan itiraf, cinsel bilimde de cinsellik üzerine "doğru” söylem üretiminin genel kalıbını oluşturmuştur. ${ }^{3}$

İtiraf yoluyla sökülüp alınan hazlar, bilimsel yöntemlerle birleşerek cinsiyete dair hakikati üretmiştir. Foucault'ya göre cinsellik, cinsel bilim tertibatıyla karşılıklı bağıntı içinde gelişmiştir. Söylem kendi hakikatini üretmiş, daha sonra cinselliği doğal olarak var olan bir şey olarak tanımlamıştır. Bu alan belirsiz nedenselliklerin

\footnotetext{
*Ankara Üniversitesi, Siyaset Bilimi ve Kamu Yönetimi
} 
odağı, ortaya çıkarılması, dinlenmesi ve yorumlanması gereken gizli ve karanlık bir kelam olarak tanımlanmıştır. Foucault'ya göre cinselliğin tarihi, bu iktidar etkilerini oluşturan söylemlerin tarihlerinden hareketle oluşturulmalıdır. ${ }^{4}$ Böylesi bir tarih çalışması için Foucault şu soruları sormayı önerir: Belirli bir tarihte ve mekânda, cinselliğe ilişkin söylemlerde ortaya çıkan iktidar bağıntıları nelerdir? Bu bağıntılar söylemleri nasıl olanaklı kılar ve söylemler bu bağıntılara nasıl dayanak oluşturur? ${ }^{5}$

Cinsellik Foucault'ya göre, iktidar bağıntılarında önemli ve yoğun bir geçiş noktasıdır, birçok strateji için dayanak noktası ve menteşe görevi görebilir. Fakat cinselliğin her türlü dışavurumuna uygulanan tek ve bütünsel bir stratejiden söz edemeyiz. Foucault, on sekizinci yüzyıldan itibaren cinselliğe ilişkin özel bilgi ve iktidar tertibatları geliştiren dört strateji ayırt eder: kadın bedenin histerikleştirilmesi, çocuk cinselliğinin pedagojikleştirilmesi, üreme davranışlarının toplumsallaştırılması ve sapkın hazzın psikiyatrikleştirilmesi. ${ }^{6} \mathrm{Bu}$ stratejiler, cinsellikle mücadele etmeyi, onu daha iyi yönetmeyi, ya da denetlemeyi amaçlamazlar; söz konusu olan cinselliği üretirler.

Bu stratejiler, yasaklamanın değil cinselleştirmenin asıl mercii olan aileden geçerler. ${ }^{7}$ Cinsellik tertibatı, on yedinci yüzyılda aile tertibatının kenarında gelişmeye başlamışken, daha sonra yavaş yavaş aileyi merkeze alarak gelişir. On dokuzuncu yüzyıldan itibaren aile, kendi içinde cinselliğin izlerinin peşine düşerek; itiraflar toplayıp kendisini sınırsızca uzmanların yorumlamasına açarak cinselleşir. Böylece, cinsellik tertibatı için en değerli taktik öğe haline gelir. ${ }^{8}$

Cinsel bilim yoluyla cinsellik, normallik talebiyle çakıştırılır, yaşam ve hastalık sorununa bağlı olarak düzenlenmeye başlar ve eski ahlakçı baştan çıkma ve aşırılık kategorileri, 'sapkınlık'ın mediko-psikolojik alanı içerisinde yayılır. ${ }^{9}$ Sapkınlıklar, çeşitlenir ve en ince detayına kadar tanımlanır. Bu gelişmeler aynı zamanda cinselliği bir tür biyolojik sorumluluk konumuna oturtmaktadır; cinsellik yalnızca kendi hastalıklarından mesul değildir, eğer denetlenmezse gelecek kuşaklara ve insan türüne kalıcı marazlara bırakabilecek bir güce sahiptir. $\mathrm{Bu}$ nedenle cinsellik giderek siyasal bir projenin parçası haline gelmiştir; cinsellik ve doğurganlık yönetilmelidir. ${ }^{10}$

\section{'Muhafazakâr modernleşme'nin cinselliği}

Cinsellik tertibatı her yerde aynı biçimde ve aynı evrelerden geçerek işlemez; bu da tek bir cinsellik tertibatının olmadığını göstermektedir. "Ĕger 'cinselliğin', karmaşık bir siyasal teknolojiye bağlı belli bir tertibatın bedenlerde, davranışlarda, toplumsal ilişskilerde yarattığı bir etkiler bütünü olduğu doğruysa, bu tertibatın her yerde simetrik biçimde işlemediğini ve dolayısıyla aynı sonuçlara yol açmadığını kabul etmek gerekir." 11 Cinsellik tertibatının belirli bir tarihsel dönemde Türkiye'de nasıl işlediğini anlamak kuşkusuz bu yazıda yapmaya çalışacağımdan çok daha kapsamlı bir analizi gerektirir. Farklı iktidar ilişkileri arasındaki bağıntıları kurmak, bunlar arasındaki söylemsel geçişlilikleri ortaya koymak ve cinselliğin farklı söylemlerin eklemlenmesine nasıl bir zemin oluşturduğunu anlayabilmek için belirli bir dönem içerisindeki toplumsal cinsiyet rejimine ve cinselliğin bu rejim içerisindeki söylemsel kurulumuna bakmak gerekmektedir. Her ne kadar, Seksoloji: Cinsî Bilgiler Mecmuası (bundan sonra Seksoloji) 1949 yılında yayım hayatına başlayan bir dergi olsa da, ben dergiyi biraz daha geniş bir tarihsel dönem içerisinde ele alacağım. Özellikle 1945 sonrası ve 1950'lerin incelenmesi, Seksoloji dergisinin nasıl bir tarihsellik içinde yayımlandı̆̆ olacaktır.

1944 yılında İsmet İnönü’nün işaretlerini verdiği çok partililiğe geçiş, 1946 erken seçimlerinde Demokrat Parti'nin meclise girmesiyle tamamlanmıştır. 1950 seçimlerinde ise DP mecliste çoğunluğu elde ederek hükümeti kurmuştur. ${ }^{12} 1950$ 'lerin ilk yıllarında başlayan tarımsal modernleşme, tarımsal işgücü fazlalığı ve sonrasında yaşanan göç, bu dönemin en önemli özelliklerinden biri olarak karşımıza çıkar. Kandiyoti bu dönemde gerçekleşen dönüşümün, Cumhuriyet reformlarının başarılı olamadığı yerde etkisi gösterdiğini, aile içindeki ataerkil otoritenin karşısına, yeni tabakalaşma süreçlerinin ve toplumsal hareketliliğin dikildiğini söyler. ${ }^{13}$ Kentleşmenin hızlanmasıyla birlikte kent-köy ayrımı keskinleşmeye başlamış, kentli ailenin düzenlenmesi acil bir mesele haline gelmiştir.

Bu dönemde Erken Cumhuriyet döneminin toplumsal cinsiyet rejimi de yeniden şekillenmiştir. Sancar, muhafazakârlar ve cumhuriyetçiler arasındaki uzlaşmayla tanımladı̆̆ı bu dönemi muhafazakâr modernleșme dönemi olarak adlandırmaktadır. ${ }^{14}$ Önceki dönemden devlet aygıtları, dinin konumu, Türklüğün tanımı gibi modernliğin üzerinde uzlaşılan öğeleri devralınırken, kadının özgürlük sınırları ve ailede kadınlara düşen roller konusunda muhafazakâr bir dönüşüm yaşanmıştır. Aile, hem cinselliğin ve modernliğin, hem de gündelik hayata dair diğer birçok meselenin (eğitim, giyim, estetik) düzenlendiği alan olarak öne çıkmıştır. ${ }^{15}$ Aile, cinsellik 
tertibatının kurulumunun ve işleyişinin de merkezindedir. Cinsel terbiye için aile hem bir amaç hem de araç olarak tanımlanır. Bu konuya Seksoloji’yi ele alırken döneceğim.

Sancar'a göre, cinsiyet ilişkilerini düzenleyen, siyasal ve toplumsal anlamlar üreten ailenin sınırları muhafazakâr modernleşme döneminde kendisini tehdit eden dişsallıklar üzerinden tanımlanmaya başlar. ${ }^{16}$ Kentli orta sınıfın yaşamı üzerinden modellenen modern Türk ailesi için, kırdan kente göç bu dışsallığın tanımında önemli bir yer tutmaktadır. Sancar, dönemin günlük gazeteleri üzerinden yaptığı incelemesinde, köylülüğün temsil ettiği cahillik, gelişmemişlik ve suç eğilimi tarafından kuşatıldığı düşünülen orta sınıf kentli ailenin, bu tehditler karşısında yapması gerekenler hakkında uyarıldığını söyler. ${ }^{17}$ Modernleşme stratejisi, Cumhuriyet seçkinlerinin yaşam tarzının, bu yaşamın stratejik düzenleme alanları olarak modern aile biçiminin ve yeni cinsiyet rejiminin, kente yeni göçenlere benimsetilmesiyle şekillenmektedir. Dönemin gazete haberleri, denetlenemeyen tutku ve duyguların getirecekleri felaketleri haberleştirerek, kentli orta sınıf aileye rehber olma, onu terbiye etme amacı taşır. ${ }^{18}$ Kurulmaya çalışılan ailenin dışsallığı yalnızca geri kalmış kırsal ile değil, aşırı Batılılaşmayla da tanımlanır. Cantek'in denetleyici $k u s ̧ a k^{19}$ olarak adlandırdığı aydınlar aile ile Türkiye'yi, mahalle ile ahlakı, Batı ile Beyoğlu'nu özdeşleştirerek yozlaşmış, tehlikeli ve anormal yaşam biçimlerine karşı gençliğe ve halka rehber olmayı amaçlamaktadır. ${ }^{20}$

Bu kuşak için, hazlar ve arzuların karşısında milli menfaatler vardır, kendileri bu arzular karşısında hem kendi nefisleriyle ve hem de mücadele vermeyip hazlar dünyasında kendini kaybedenlerle, yozlaşanlarla mücadele ederler. ${ }^{21}$ Cinsellik ise hem yozlaşmanın hem de gayri medeniliğin merkezinde yer alır. Kadınlar ve gençlerin denetlenemez cinsellikleri en çok sorunlaştırılan meselelerden birisidir. ${ }^{22}$ Kadınların lüks ve sefahat düşkünlüğü, ailenin çözülmesine neden olmaktadır. ${ }^{23}$

Aslında gençlerin, kadınların, Batı kültürünün, lüks tüketimin simgelediği şey cinsellik ve hazlar dünyası gibi görünmektedir. Aileyi tehdit eden bu hazlar ve cinsellik dünyasıdır. Cinsel ahlak açısından yeterince terbiye edilmemiş, tutkularının esiri olmuş tiplerin yanlış davranışları 1950-1965 dönemi günlük gazetelerinde suç söylemi çerçevesinde ele alınmıştır. ${ }^{24} \mathrm{Bu}$ çerçevede ötekinin cinselliği, düzensizlikle, ahlak dışılıkla, gayri medeni olmakla, yasa ve norm dışılıkla, şiddetle tanımlanmaktadır. Suçun tanımı genişletilmekte, kadın-erkek arası norm dışı birliktelikler; gençlerin cinsel ilişkileri, evlilik dışı ilişkiler kriminalize edilmekte, ahlak ve düzen sorunu olarak görülerek devletin müdahale alanına sokulmak istenmektedir. ${ }^{25}$ Kadınlara yönelik şiddet içeren tecavüz, cinayet gibi eylemlerle, her türlü cinsel ilişki aynı biçimde haberleştirilmekte, cinsellik ve güvenlik sorunu haberlerde iç içe geçmektedir. "Muhafazakâr modernliğin cinsellik düzenlemesinin kendinden menkul bir modernlik tanımı yaptığını, cinselliğin kamusal bir mesele olarak devletin ve genel olarak 'kamu'nun müdahale alanı içinde olduğunu görüyoruz."26 ,

$\mathrm{Ne}$ var ki, her türlü cinselliğe benzer araç ve yöntemlerle yaklaşılmamakta, kadınların, gençlerin, çocukların, taşralıların cinselliklerine karşı farklı ahlaki kriterlerle yaklaşılmaktadır. Yukarıda da belirttiğim gibi cinsellik tertibatı tek bir söylem tarafından yapılandırılmamıştır; farklı cinselliklere yönelik geliştirilen farklı araç ve yöntemler cinsellik tertibatının farklı söylemselliklerle eklemlenişini de gösterir. Günlük gazete haberlerinde erkek eşcinselliği yozlaşma ve cinsi sapıklık olarak sunulurken, ${ }^{27}$ tecavüz, kız ve kadın kaçırma, bekâreti bozma gibi cinsel suçlar gayri medenilik çerçevesinde ele alınır. ${ }^{28} \mathrm{Bu}$ farklı cinselliklere yönelik kâh cezai araçlar, kâh eğitimsel araçlar kâh tıbbi araçlar devreye sokulur. Bu araçların ve söylemlerin, Seksoloji dergisinde cinsel terbiye başlığı altında eklemlendiklerini göstermeye çalışacağım.

Burada kast edilen cinsel terbiyenin işlevini, hazları ve arzuları bastırmak, denetlenemez cinselliği düzenlemek gibi yorumlamak Foucault'nun baskıcı varsayıma karşı eleştirileri akılda tutulduğunda pek de mümkün olmayacaktır. Cinsel terbiye altında birleşen söylemler, düzenlediklerini iddia ettikleri alanı tanımlar, üretirler de. Türk modernleşmesi bağlamında cinselliğin düzenlenmesi, yeni arzuların tanımlanmasını, tasnif edilmesini, bilimselleştirilmesini, bazılarının kriminalize edilmesini - en azından bu yönde bir girişimi - işaret etmektedir. Bu girişim, her ne kadar kendisini öyle konumlandırsa da, arzuları kışkırttığı söylenen popüler kültür ürünleriyle mutlak bir karşıtlık içerisinde değildir. Denetleyici kuşak denetlenemez olduklarını söyledikleri arzuları kışkırtmaktadır. Kendilerine biçtikleri rol arzuların karşısında fedakâr olmak, milli menfaatler için adeta bir nevi perhiz yapmak olsa da, lanetlenen aynı zamanda arzulanası olan olarak kurulmaktadır. Cantek'in de söylediği gibi bu kuşağın üyeleri, lanetledikleri arzular dünyasını şehvetle anlatırlar. "O sahte, aldatıcı, uçarı cazibeyi tanımlarken bile heyecanlıdırlar, ne yazarlarsa yazsınlar şehrin (Türkiye'nin) hiçbir yerinde olmayan ve yaşanmayan cezbedici bir hayatı anlatmaktadırlar." 29 Denetleyici kuşak, kendilerini karşısında konumlandırdıkları dünyanın dışında değildir; fakat bu hazlar dünyasını bir dışsallık olarak kurarak toplumu düzenleyici, terbiye edici söylemsel bir alan kurarlar. Hazlara karşı nefislerini denetleme çabaları, bedeni ve 
hazları dışarıda bırakıyormuş gibi görünse de, bedeni tam da siyasal ve toplumsal düzenlemenin merkezine oturtmaktadır. Düzenlenmesi gerektiği söylenen cinsellik alanı kurucu elitler tarafından tanımlanmakta, sınırları çizilmekte bir yandan da kışkırtılmaktadır.

\section{Seksoloji: Cinsi Bilgiler Mecmuası}

Seksoloji: Cinsi Bilgiler Mecmuası, "cinsî terbiyede salâhiyetli bir rehber” olma iddiasıyla Nisan 1949 yılında yayımlanmaya başlamıştır. Aylık bir dergi olan Seksoloji, 1954 yılı Mart ayında 'daha geniş kütlelere hitap etmek, daha tesirli şekilde faydalı olmak imkânlarını araştırmak' amacıyla yayım hayatına son vermiştir. ${ }^{30}$

1930lardan 1960ların sonuna kadar ABD'de aynı isimli (Sexology) bir dergi yayımlanmıştır. İki derginin içeriği büyük ölçüde örtüşmektedir ve Seksoloji'de bu dergiden çeviriler bolca yer alır. ${ }^{31}$ Yalnızca ABD'deki adaşından değil, Avrupa'daki kadın ve evlilik dergilerinden, popüler cinsellik kitaplarından ve cinsel bilim yayınlarından çeviriler Seksoloji'nin içeriğinin önemli bir kısmını oluşturmaktadır. Çevirinin cinsellik biliminin aktarılmasında ve yeniden yorumlanmasında oynadığı rol, cinselliğin söylemsel kurulumunu farklı bağlamlarda incelemek için önemlidir. ${ }^{32}$ Cinsellik biliminin Türkçeye çevrilmesini ve yorumlanmasını incelemenin, cinsel terbiyenin Türkiye'de kazandığı özgün biçimi anlamak açısından önemli olduğunu düşünsem de, bu yazıda Seksoloji'nin çoğunlukla hekimlerden, yanı sıra hukukçulardan ve Cantek'in denetleyici kuşak olarak adlandırdığı entelektüellerden oluşan ekibinin yazılarına odaklanacağım.

Derginin ismini koyan Fahreddin Kerim Gökay'dır. Gökay ${ }^{33}$ gibi önemli isimlerin Seksoloji'ye dair görüşlerine, özellikle de ilk sayılarda sıkça yer verildiğini görüyoruz. Bu durum, derginin yayın hayatı boyunca devam eden kendisini meşrulaştırma çabasının bir parçası olarak görülebilir. Dönemin dergilerinde karşılaştığımız entelektüellerle yapılan anketler, ${ }^{34}$ Seksoloji'nin 1949 yılındaki sayılarında da yapılmıştır ve bu anketlerde Peyami Safa, Selim Sırrı Tarcan ${ }^{35}$ gibi isimlerin Seksoloji'nin memleket için, özellikle de memleket aydınları için önemli bir girişim olduğuna ilişkin görüşleri alınmıştır.

Cinsellikle ilgili bir dergi çıkarmanın yayımcılar için zorlayıcı yanları, Seksoloji'nin ikinci cildinin ilk sayısının giriş yazısında şöyle açıklanmaktadır.

Bizi; temiz kalmayı ve yurt hizmetinde çalışmayı gaye edinmiş insanlar olarak tanıyan dostlarımız; aşinalarımız; bir gün bir cinsî bilgiler mecmuası çıkarmaya karar verdiğimizi işittikleri zaman ya üzüldüler veya şüpheye düştüler. Üzülmelerine; şüphelenmelerine hak verdik: çünkü bu mevzuun bütün istismar imkânlarını son hudutlarına kadar denemiş ve denemekte olan çeşitli neşriyat ortada duruyordu; bizim de aynı sahaya el atmamız zihinlerde haklı olarak bir istifham [soru] uyandıracak ve teşebbüsümüzde şüpheli motifler arayacaklardı. ${ }^{36}$

Cinsellikten bahsetmek, cinselliğe ne kadar bilimsel yaklaşılırsa yaklaşılsın utanç hissi uyandırmaktadır. On dokuzuncu yüzyıl psikiyatristleri, ırza geçmeden, hayvanlarla seksten, eşcinsellikten bahsederken bu aşağılık sapkınlıkları dile getirmekten kaynaklı bir utanç içindedirler. ${ }^{37}$ Öznenin karanlık yanlarını ortaya çıkardığını iddia eden cinsel bilime utancın eşlik etmesi çok da şaşılası görünmemektedir. Fakat Cocks'un dikkat çektiği gibi bu utancın başka bir nedeni daha vardır: Özellikle 20. yy başlarında pornografi, cinsel bilim yayınlarıyla aynı kanallardan okuyuculara ulaşmaktadır; bu nedenle cinsel bilim kendisini sürekli pornografiden ayırma ihtiyacı hissetmektedir. ${ }^{38}$

Seksoloji de, Avrupa'daki öncelleri gibi kendisini muzır neşriyattan kesin bir biçimde ayırmaktadır. Seksoloji'nin amacı, dünyanın birçok yerinde, özellikle de Batı ülkelerinde ciddiyetle ele alınan cinsel bilim ve terbiyenin Türkiye'de de aynı ciddiyetle ele alınmasını sağlamak, "cinsi terbiyede salahiyetli bir rehber" olmaktır. Fakat ahlaksızlıkla, dejenerelikle yaftalanmaktan çekinmektedirler. Gayri medeni taşralılığın ve yoz modernliğin alanı olan cinsellikle uğraşmak risklidir, kendilerini bu ikisinden sürekli ayırmak zorundadırlar. Bu anlamda denetleyici kuşağın önemli bir temsilcisi olan Peyami Safa'nın 1951-1952 yıllarında dergide düzenli biçimde yazması önemli görünmektedir.

Kendini meşrulaştırma çabasının bir parçası olarak, derginin halk ve resmi otoritelerce ne kadar desteklendiğinin altının çizilir. Derginin sorumlu yazı işleri müdürü Muzaffer Aşkın, kırkıncı sayıya yazdığı önsözde iyiyi ve kötüyü ayırmayı iyi bilen halkın güveninden ve desteğinden; adli makamların resmi otoritelerin olgunlukla gösterdikleri anlayıştan söz eder. ${ }^{39}$ Seksoloji'nin verdiği cinsel terbiyenin hayati önemini taşra da takdir etmektedir. "Seksoloji memleket matbuatında nasıl karşılandı?" isimli tanıtım yazısında, derginin 'takip ettiği davanın hak ve meşruiyetini ispat' için Sivas, Aydın, Edirne, Gaziantep, Erzurum, Niğde, Kastamonu'dan yerel gazetelerin dergiden övgüyle bahseden haberlerine yer verilmektedir. Yerel gazeteler, şimdiye kadar 
ciddiyetle ele alınmamış cinsî terbiye mevzusunun Seksoloji'de en salahiyetli uzmanlarca ele alındığını, derginin temiz ve ahlaklı bir üslubu olduğunu vurgulamaktadır. ${ }^{40}$

\section{'Cinsî terbiyede salâhiyetli bir rehber'}

Cinsel terbiyeyi gerekli kılan yozlaşma ve gayri medenilik, aileyi ve toplum sağlığını tehdit etmektedir. Gayri medenilik, cinselliği konuşulmaması gereken bir ayıp olarak niteleyen söylemlerde, yozlaşma ise kadın erkek arası ahlaksız ilişkilerde ve sapkınlıklarda somutlanır. Bunların sonuçları cinsel hastalıklar, sapkınlıklar ve evlilik bağının zayıflamasıdır. Sonuç olarak sağlıklı nesiller yetişemez, ulusun geleceği tehlike altına girer. Bu düşünce doğrultusunda cinsellik ve doğurganlık, ailelerin, devletin ve özellikle de halka yol gösterecek aydınların, entelektüellerin sorumluluğu haline getirilir. Sorumluluğun kapsamı, farklı söylemlerin eklemlenmesiyle oluşan 'cinsel terbiye' kavramıyla tanımlanır. Bu söylemler arasında en belirgin olanlar, pedagoji, bilim, ahlak, suç/sapkınlık söylemleridir. $\mathrm{Bu}$ bölümde bu söylemlerin Seksoloji’de nasıl eklemlendiklerine bakacağım.

Cinsel terbiye, yokluğunda ortaya çıkacak felaketlere dair tehditler savurarak kendini gerekli kılar. Toplumun içerisinde bulunduğu bilgisizlik, aile içinde ve dışında sorunlara yol açmaktadır. Sağlam bir aile kurmak için bireylerin cinsel terbiyeye, doğru cinsel bilgiye ihtiyaçları vardır, aksi takdirde anti-sosyal ve psikopatolojik sonuçlar doğacaktır. ${ }^{41}$ Geçmişte olduğu gibi bağnazlıktan kaynaklı bir cehalet, toplumu felakete sürükleyecektir. Her ne kadar "geçmişin" ne olduğu, cinselliğin bu müphem geçmişte nasıl olduğu net bir biçimde ortaya konulmasa da, bugünün durumu geçmişten gelen alışkanlıklarla açıklanmaktadır. ${ }^{42}$

$\mathrm{Bu}$ sorunların önlenmesi için, cinsel terbiyenin en erken yaşlardan itibaren çocuklara verilmesi gerekmektedir. 1950 yılında Seksoloji okurları arasında yapılan bir yarışmada, okuyuculardan derginin ilk altı ayında yayımlanan yazılar arasından çok beğendikleri bir tanesini seçmeleri ve neden bu yazıyı seçtiklerini açıklamaları istenmiş. Yarışmanın neticesinde ilk üçe giren okurların hepsi de derginin birinci sayısında yayımlanan "Çocuklara cinsiyetten nasıl bahsetmeli?" isimli yazıyı seçmişler. ${ }^{43}$ Mektuplar, okurların şu fikirde birleştiklerini gösterir: Memlekette cinsel konular ayıp sayıldığından çocuklara anlatılmamaktadır, çocuklar ergenliğe girdiklerinde doğal cinsel dürtülerinin etkisi altında cahilliklerinden yanlış yollara saparlar, bu yüzden kurdukları aileler de sağlam olmaz ve ulusun temeli olan aile kurumu sağlam olmadığında ulus gelişemez. ${ }^{44} \mathrm{Bu}$ temel iddia cinselliğe pedagojik açıdan yaklaşan yazıların birçoğunda farklı biçimlerde ele alınmıştır.

Cinsellik eğitiminde ailelere büyük sorumluluk düşse de, bu sorumluluk sadece onlara bırakılamaz. Cinsellik, mili eğitim müfredatına da girmelidir. Dönemin ilk ve orta öğretim fen ve sağlık kitaplarını inceleyen Faruk Akbeğ, kitaplarda cinselliğe ya hiç değinilmediğini ya da üstünkörü bir biçimde değinildiğini söyler. ${ }^{45}$ Cinselliğin terbiyesizlik olarak anlaşıldığı dönemler geride kalmıştır; cinsellik artık öğretimde de tabu olmaktan çıkartılmalıdır. ${ }^{46}$ Böylece cinselliğin devletin sorumlulukları arasında olduğu hatırlatılır ve ulusun terbiyesine yönelik siyasal projenin bir parçası olması gerektiği vurgulanır.

Şekip Tunç'a göre cinsellik konusundaki terbiye, yalnızca bilimsel ve teknik değil, aynı zamanda arzuları düzenleyebilmek için hissî de olmalıdır. ${ }^{47}$ İnsanlarda hayvanlardakinden farklı olarak cinsiyet heyecanı yalnızca içgüdüsel değildir, toplumsal ve ruhsal bir içerik kazanmıştır. Bu nedenle, cinsel hayatın gayesi yalnızca haz olmayıp, hazların en kuvvetlisi olan sevgi bağıdır. ${ }^{48}$ Bedensel olan en bilimsel yöntemlerle düzenlenirken, ruhsal olandan bağımsız olmamalıdır. Peyami Safa için de cinsel organlar, organların işleyişleri gibi bilgileri içeren cinsel öğretim ile cinsel eğitim birbirlerinden farklıdır: "Cinsî eğitimin amacı bilgi vermek değil, cinsî enerjinin, normal tenasül faaliyetlerinin istediği dereceyi aşan fazla taraflarını beden ve daha ziyade ruh için yararlı enerjilere yükseltmektir." ${ }^{\text {"9 }} \mathrm{Bu}$ söylemde beden ancak, ruhsal olanın koşul olduğu anda düzenlenmek için çağrılmaktadır. Çağırılan beden, bilimsel söylem yoluyla doğal beden olarak kurulmaktadır da. Beden ve ruh arasında kurulan bu ilişkinin bu yazı çerçevesinde ayrıntılı bir eleştirisini geliştirmek mümkün olmasa da, cinsel terbiyenin, 'bedeni ruhun hapishanesi' olarak üreten söyleminin altını çizmekte fayda var.

Cinsel terbiye özellikle, toplumsal hayattaki hızlı dönüşüm yüzünden gereklidir. Kadın ve erkeğin bir araya geldiği toplumsal alanların artması, her iki cinsin arzularının tehlikeli biçimlerde karşılaşmasına neden olur. Fakat bu arzular kadında ve erkekte aynı biçimde bulunmamaktadır. Yazılarda erkeğin doğasından kaynaklı denetlenemez cinsel arzularının olduğu söylenirken, bazı kadınların arzularının doğal olmayan biçimde arttığından da şikâyet edilir. 'Sözde kızlar'ın ${ }^{50}$ ayrıntılı bir dökümünü sunan Peyami Safa, birinci dünya savaşından sonra kadın ve erkeğin bir araya geldiği mekanların artmasıyla cinsel arzularının kölesi 'sözde kız' tipinin yaygınlaştı̆̆ından söz eder. ${ }^{51}$ Sözü geçen toplumsal mekânlar alkolün bolca tüketildiği eğlence mekanları 
ya da plajlardır. Böylece cinsellik yine sefahatin, sorumsuz eğlencenin alanına çekilerek tarif edilir. Safa, bu mekanları ve sözde kızları anlatırken arzuyu kışkırtan şehvetli bir dil kullanır.

Cinsellik konusunda bilimsel bilgi, cinsel terbiyenin en önemli unsurlarından biridir. Her alanda olduğu gibi cinsellik alanında da, bilimsel yaklaşım en doğru ve şaşmaz temeli sunmaktadır. Akbeğ, lise sağlık bilgisi derslerinde cinsel hastalıkların öğretilmesinin önemli olsa da yeterli olmadığını, asıl olarak cinsel organların yapısı, işleyişi ve cinselliğin psiko-fiziksel yansımalarının öğretilmesinin gerekli olduğunu söyler. ${ }^{52}$ Akbeğ, cinsel organların ayıp kabul edildikleri için fen kitaplarında yer almadığından şikâyet ederken, on dokuzuncu yüzyılda cinsellik tertibatının ortaya çıkmasıyla birlikte özerkleştirilen cinsel organları ${ }^{53}$ cinsel terbiye için öğrenilmesi gerekli doğal, anatomik gerçeklikler olarak sunar.

Dar anlamıyla cinsellik bilimine ilişkin, Türkiyeli hekimler tarafından kaleme alınmış makaleler ve çeviriler neredeyse her sayıda yayımlanmıştır. Özellikle cinsel hastalıklarla ilgili yazılara sıkça rastlanır. Cinsel organların işleyişi, bu organlar ve cinsel arzular arasındaki ilişki gibi konuların yanı sıra iktidarsızlık, kısırlık, bel soğukluğu, kadınlarda cinsel soğukluk cinselliğe özgü hastalıklar olarak ele alınır. Her sayının en sonunda yer alan "Sual ve cevaplar" bölümünde bu konulardaki sorulara hekimler cevap verir. Mektuplar genelde okuyucuların çaresiz yakarışlarıyla sonlanır. Bu mektuplardan anlaşıldığı kadarıyla okurlar da Seksoloji'yi başka yerde yanıt bulamadıkları sorularına cevap verebilecek 'yetkili bir rehber' olarak görmektedirler.

Cinsel rahatsızlıklar, cinsel terbiyenin eksikliğinden kaynaklanan önemli bir sorunlardan biridir. Karçal ve Uraz, cinsel hastalıkların büyük şehirlerde köylere göre, talebe tüccar arasında işçi ve askere göre daha yaygın olmasını, Krafft-Ebing'e referans vererek, 'ileri kültürler'in denetimsiz cinsel arzular için zemin hazırladığını söyleyerek açıklarlar. ${ }^{54}$ Ahlaki ve dini terbiyenin eksikliğiyle birleşince bu durum, evlilik dışı ilişkilerin ve cinsel hastalıkların artmasına neden olmaktadır. Cinsel hastalıklar, toplumdaki yozlaşmanın sonucu oldukları kadar, zararlıdırlar da. İstanbul'da frenginin tehlikelerine dikkat çekmek için Ata Tokgöz şöyle demektedir:

Günlük hayatın ve münasebetlerin çok kesif olduğu böyle bir şehirin sokaklarında tedavisiz, kendini bilmeden dolaşacak bir frengilinin, bir gonorelinin yalnız kendisi ve etrafındakiler için değil, fakat bütün bir şehir hattâ memleket için nasıl bir hastalık ve felâket kaynağı olacağ bellidir. ${ }^{55}$

İstanbul ve frengi arasında ilişki kuran yalnız Tokgöz değildir. Frengi, Türkiye modernleşmesinde ahlaki yozlaşmayı temsil eden hastalık gibi görünür. Cantek'in de işaret ettiği gibi, romanlarda Batı hayranı alafranga tiplerin sonu frengiyle biter ve Sifiliz hastalığına verilen isim bile frenk'e, Batılı yabancıya ait anlamındadır. ${ }^{56}$

Frengiyle 'neredeyse ayrıştırılamayacak kadar bütünleşmiş' olan fuhuş ${ }^{57}$ da Batılılaşmanın getirdiği sorunlardan biri olarak ele alınmaktadır. ${ }^{58}$ Fakat fuhşun yasaklanması kesinlikle önerilmez. İstanbul'da Emrazı Zühreviye Müdürü ve aynı zamanda İstanbul Fuhuşla Mücadele Komisyonu âzası olan Seyfettin Atalan, Seksoloji'de yayımlanan röportajında fuhşun yasaklanmasının cinsel hastalıkları artıracağını söyler. ${ }^{59}$ Erkeklerin denetlenemez cinsel arzuları fuhşu zorunlu kılar.

Cinsiyet, insanları kıskıvrak saran ve tatmini bir zaruret olan kuvvetli bir insiyak [içgüdü] olduğuna göre, ekonomik ve sosyal, türlü saiklerle evlenmesi geciken erkeğin bu insiyakını düşünmek icabeder. Esasen tabiat onu şiddetle bu yola sevketmektedir. Cemiyete düşen vazife, bu işin sıhhî ve içtimaî bir disiplin dahilinde organize edilmesidir. ${ }^{60}$

Genelevler, bu arzuların kamusal düzen bozulmadan giderilebilmesi için gerekli yerlerdir. ${ }^{61}$ Fuhşun yasaklanması hem cinsel hastalıkların yayılmasına, hem de tecavüz, sarkıntılık gibi toplumsal düzeni bozan ahlaka aykırı suçların artmasına neden olacaktır. Fakat Sancar'ın da söylediği gibi fuhşa dair üretilen söylem değişik noktalarda sıkışmaktadır. Örneğin günlük gazetelerde, kadınlara musallat olan 'kandırma şebekeleri'nin kadınları kötü yola düşürme haberleri, yukarıdaki düşünceyle birlikte yer alır. ${ }^{62}$ Seksoloji'de de, fuhşun çelişkili biçimlerde ele alındığını görüyoruz. Nihat Sami Banarlı, 'kötü yola düşen masum bir genç kız'ın hikâyesini anlattığı "Seni düşüren eller" isimli yazıda şöyle demektedir: "Sizler... Vatanın dünkü masum ve sevgili kızları, sizler bizim iç kalelerimizsiniz. Sukutunuz bütün bir milleti içten yıkacak kadar müthiş ve hazindir." ${ }^{63}$ Fakat her ne kadar kadınları 'hayvanî zevklerin en basit ve en adî bir aleti haline sokan' fahişelikten kurtarmak cemiyetin vazifesi olsa da, 'cemiyetin selameti, ferdin sıhhati ve aile iffeti' için bu duruma katlanmak zorundayızdır. ${ }^{64}$ Bazı kadınlar ailenin namusunun korunması için adeta feda edilmektedir. Böylece, kadınlar fuhuş söylemi içerisinde evli kadınlar ve fahişe kadınlar diye ikiye ayrılmaktadır. ${ }^{65}$

$\mathrm{Bu}$, mesleki veya medeni duruma dair bir ayrımdan çok, neredeyse doğuştan gelen bir farktır. Erkeklerin cinsel arzularının denetlenemezliği tartışılmazken, bazı kadınlarda cinsel arzuların fazlaca bulunması 
bir sapkınlık olarak ele alınır. Peyami Safa'nın sözde kızları, bu cinsten aşırı cinsel arzuları olan kadınlardır. 'Namuslu kadın'ı 'namussuz olan'dan ayırt etmek kolay değildir; fahişelerin arasında temiz ahlak ve namus sahibi kadınlar olabileceği gibi, evli kadınlar ya da bakire genç kızlar arasında da ahlakı bozuk olanlar bulunabilmektedir. Bu kızlar, ahlaksız ilişkilere girdikçe ahlak duyguları daha da zayıflar ve nihayetinde manevi hayatları tamamen kurur. Buhran dönemlerinde bu tip kızların sayısı daha da artar. ${ }^{66}$ Dergide bu iki uç arasında yer alan, arzularına yenik düşen ya da kandırılarak namusunu kaybeden genç kızlardan da sıkça söz edilmektedir. Özellikle hekimlerin aktardığı vakalarda, bekâret sorunu çerçevesinde bu kadınların hikâyelerini duyarız. ${ }^{67}$

Cinsel terbiye söylemine göre, terbiyenin eksikliği, bireyi ve toplumu yalnızca hastalığa ve ahlaksızlığa değil, suça ve sapkınlığa da sürüklemektedir. Akbeğ, İstanbul Üniversitesi Türk kriminoloji enstitüsünün Temmuz 1944 ile 1945 yılları arasındaki verilerinden yararlanarak, bu dönemde işlenen cinayetlerin büyük çoğunluğunun cinsellik kaynaklı olduğunu söyler. ${ }^{68}$ Akbeğ'e göre, bu suçların önlenmesi için çocuklara küçük yaştan itibaren cinsiyet eğitimi verilmesi gerekmektedir.

Suçlar arasında en göze çarpanlardan sarkıntılık, özellikle 1950'lerde günlük gazetelerde fazlaca ele alınan bir konu haline gelmiştir. ${ }^{69}$ Seksoloji'de de sarkıntılık cinsel terbiye eksikliğinin büyük şehir sokaklarındaki en görünür hali olarak sıklıkla anılmaktadır. Hukuksal alanda yazılar yazan Ferit Hakkı Saymen sarkıntılığı, uzun seneler süren dini baskı altında kadınların kapatılmasının, çocuk ve gençlerin cinsel terbiye almamalarının, kız ve erkek çocuklarının ayrı tutularak cinsel arzularını kamçılayan bir sistemde yetişmelerinin sonucu olarak görür. ${ }^{70}$ Sarkıntılık, yalnızca ona maruz bırakılanı değil, kamusal alanda gerçekleştiğinden herkesi rahatsız etmektedir. ${ }^{71}$ Sarkıntılı̆̆ın, kamusal alanda cereyan etmesi onu toplumsal bir mesele haline getirmiş gibi görünmektedir. Sancar, büyük kentlerin seçkin semtlerinde sarkıntılığın hiç hoş görülmediğinden, modernliği bozan bir durum olarak kodlandığından söz eder. ${ }^{72}$ Fakat sarkıntılık aynı zamanda modernliğin getirdiği bir sorundur. $\mathrm{Bu}$ çerçevede sarkıntılıktan, erkekler kadar kadınlar da sorumlu tutulur. Yoz modernleşmenin temsilcisi (kentli) kadınlar, bu düzen bozucu fiilin ortaklarıdır. Kadın bedeni parçalara ayrılır, koltukaltı, sırt, kalça gibi beden parçaları cinselleştirilir, sarkıntılığın failleri olarak adlandırılır. Derginin "Birkaç söz" başlıklı kapak yazısında yer alan şu sözler çarpıcıdır:

Koltuk altlarını ve göğüslerini gösteren Japone elbiselerle caddelerde dolaşan; ancak plâjlarda giyilebilecek sırtı ve omuzları uryan askılı roblarla ara sokaklara giren, yahut tekmil vücut ve bilhassa kalça hatlarını haykıran dar ipekli elbiselerle tramvaya, otobüse binmekten çekinmeyen hanımları biz, sarkıntılık fiillerinin asgarî yüzde ellisinden mesul görüyoruz. Zira bu şekilde giyinmek bile başlıbaşına sarkıntılık sayılabilir. ${ }^{73}$

Tecavüz dergide nispeten az ele alınsa da, taciz gibi modern yaşamı ve aileyi tehdit eden bir unsur olarak sunulur. Yukarıda da söz ettiğim, bekâret bahsinde geçen yazılarda, adı böyle konulmasa da aslında tecavüz olayları anlatılmaktadır. Bunların yanı sıra tecavüz, suç ve sapkınlık söylemlerinin kesişiminde ele alınır. "Sarıyer cinayeti ve sadist psikopatlar," "Londra Landrusu ve cinsî azgınlık" gibi yazılarda Akbeğ, tecavüzü patolojik bir durum olarak ele alır. Her iki makale de tecavüz ettiği kadınları öldüren, seri cinayetler işleyen erkeklerden bahseder. Makaleler daha çok bu adamların psikopatolojisini analiz etmeyi amaçlar. ${ }^{74}$ Dergideki anlatıya göre tecavüz, az rastlanan patolojik bir durumdur ${ }^{75}$ sarkıntılık kadar yaygın biçimde toplumsal hayatı sarsmaz, genel ahlakı zedelemez. Tecavüz, kız kaçırma, bekâret bozma gibi suçlar çerçevesinde ele alınırken gayri medeniliğin bir alameti olarak gösterilir. Bu bağlamda taciz ve tecavüz, fuhuş gibi, erkeklerin denetimsiz cinsel arzularıyla açıklanır. Patolojikleştirildiğinde ise, toplumsal hayat için daha az tehlikeli, az rastlanır bir maraz haline gelir. Her iki durumda da tecavüz, bir iktidar sorunu olarak değil -normal veya anormal- erkek fizyolojisinin bir sonucu olarak açıklanmaktadır. Yine her iki durumda da, şiddet ancak aileyi ve toplumu tehdit ettiği ölçüde cinsel terbiyeye aykırı bir sorun olarak sunulur.

Cinsel bilim tarafından tanımlanan diğer sapkınlıklara da dergide değinilmektedir. Fakat bu sapkınlıklar - fetişizm, nekrofili, sadizm, zoofili -ciddi tehditler olarak değil, sıra dışı ve yabancı olaylar olarak ele alınmaktadır. Sapkınlıklarla ilgili yazılar genellikle yabancı kaynaklardan çevirilerdir, fakat sinir ve ruh hastalıkları uzmanı Aydın Uluyazman çoğu 1952'de olmak üzere cinsel sapkınlıklarla ilgili yazılar yazmıştır. Bu yazılarda değinilen vakalar, yine yabancı kaynaklardan derlenmiştir.

Eşcinsellik de sapkınlıklar başlığı altında, hem bir sıra dışılık hem de kentli hayatın yol açtığı yozlaşmalardan birisi olarak karşımıza çıkar. Cinselliğin kent hayatındaki tehdit edici boyutları, çocukları cinsel sapkınlıklardan - ya da daha açık ifadesiyle eşcinsellikten - koruma gereğini de ortaya çıkarmıştır. Dr. Kemal Çağlar, 25 yıl öncesine kadar çocukların, ailelerinin dizlerinin dibinden ayrılmazken bugün tiyatro, kahve, 
gazino ve plaja tek başlarına gittiklerini, 'dejenereler'in buluşma yeri olan tramvaylara tek başlarına bindiklerini ve buralarda iğrenç adamlar tarafından kolaylıkla tuzağa düşürülebileceklerini söyler. ${ }^{76}$ 'İğrenç'in, 'dejenere'nin ne veya kim olduğu açıktır, fakat adı zikredilmez. Sıklıkla doğuştan gelen eşcinselliğin, bazı Batı toplumlarında açıkça savunularak geliştiği söylenir. ${ }^{77}$ Cinsel baskı da aynı şekilde eşcinselliğe neden olabilmektedir. Faruk Akbeğ'e göre kadınlar, bekâretlerini kaybetme korkusu ve toplum baskısı yüzünden cinsel isteklerini erkeklerle tatmin edemezler ve kadınlara yönelmeye başlarlar. ${ }^{78}$ Kadın eşcinselliğini önlemenin yolu da yine cinsel terbiyeden geçmektedir:

Evlenmemiş kız ve dul kadınların böyle sevicilik cinsî tersliklerle yaşamaları kendileri için bir bedbahtlık, cemiyet için de bir kayıptır. Onları bu bedbahtlıktan kurtarıp cemiyete faydalı birer uzuv haline getirebilmek için zihinlerde kökleşmiş olan kadın - erkek cinsiyet tezadını yumuşatmak; ne erkeğe hudutsuz bir cinsî serbestlik tanımak, ne kadını mutlak bir cinsî mahrumiyet içine hapsetmek ... Bu da halka, aile ve okullarda çocuklara verilecek cinsî terbiye ile ancak uzun bir zamanda mümkün olabilir. ${ }^{79}$

Seksoloji yazarı hekimlerden Sadi Irmak'a göre cinsel sapkınlıklara karşı, insanlığın geliştirdiği biricik kurum ailedir. ${ }^{80}$ Foucault'nun gösterdiği gibi, aile tertibatının doğurganlığın düzenlenmesinde, cinselliğin tıbbileştirilmesinde ve psikiyatrikleştirilmesinde bir kaide işlevi görmüştür. ${ }^{81}$ Ailenin üstlendiği bu işlevi, Seksoloji dergisinde de takip etmek mümkündür. Bir sonraki bölümde cinsel terbiyenin nihai hedefi olarak ailenin düzenlenmesi ve sağlıklı nesillerin yetiştirilmesi konularının dergide nasıl ele alındığını işleyeceğim.

\section{Seksoloji’de aile ve doğurganlığın düzenlenmesi}

Ailenin korunması ve güçlendirilmesi, cinsel terbiyenin hem amacı hem de aracıdır. $\mathrm{Bu}$ nedenle aile içi ilişkilerin düzenlenmesi hayati önem taşır. Evlilikte cinsel hayat, eşlerin cinsel uyumu, evli kadınların cinselliği gibi konuların yanı sıra, çocukların yetiştirilmesi ve eğitimi de Seksoloji'de ayrıntılı biçimde ele alınmıştır. Evliliğe ve eşler arası ilişkilerin düzenlenmesine ilişkin yazılar ise cinsellikle sınırlı değildir; eşlerin birbirlerine karşı görevleri - tahmin edileceği üzere daha çok kadınların görevleri - evlilikte aşk, geçimsizliğin nedenleri gibi yazılara da sık sık rastlamak mümkündür. Zaten, aynı adla kurulan yayınevinin de ilk kitapları Mükemmel İzdivacın Şartları (1950) ve İşte Evlendiniz (1950) başlıklı çevirilerdir. ${ }^{82}$

1950ler ailenin ve evliliğin giderek daha net tanımlandığı bir dönem olarak karşımıza çıkar. Aile ve kadın imgelerinin inşasının yakından gözlemlenebildiğini bu dönemin tipik özelliği, egemen konumdaki erkeklerin güzel kadınlarla evlenerek kuracakları modern yuva düşüncesidir. ${ }^{83} \mathrm{Bu}$ dönemde, günlük gazetelerde, kadın ve dergilerinde olduğu gibi Seksoloji'de de eşlerin, özellikle de kadınların, üzerlerine düşen görevlerin tanımlandığı birçok yazıya rastlarız.

1953 yılında Seksoloji aileye daha fazla yoğunlaşmaya karar verir. "Aile mecmuası Seksoloji” başlıklı yazıda şöyle denmektedir: "İlk sayılarında ve ciltlerinde hemen tamamiyle cinsi hayatın teknik tarafiyle meşgul olan mecmuamız, üç ayda bir çıkan ek yayınlarının da yardımiyle bu sahadaki ilk tecessüsleri [merakı] tatmin ettikten sonra, şimdi yavaş yavaş tam bir aile mecmuası olma yoluna girecektir." ${ }^{44} \mathrm{Bu}$ doğrultuda "Ailede sağlık" isimli bir bölüm dergide yer alır. Ayrıca, Abraham Stone ve Hannah Stone'un A Marriage Manual: A Practical Guide to Sex and Marriage (1935) isimli kitaplar1, "Evlilik Rehberi" ismiyle tefrika edilir. Bu dönüşüm, ileride daha ayrıntısıyla bahsedeceğim Amerikan seksolojisiyle kurulan ilişkilerin sıkılaşmasıyla ilişkili olsa da, 1950'lerden itibaren ailenin kazandığı önem bağlamında da değerlendirilmelidir. ${ }^{85}$

Toplumsal alandaki değişimlerin evlilik ve aile üzerinde yarattı̆̆ı etkilerle başa çıkabilmek, evliliğe ilişkin makalelerin en önemli hedeflerindendir. Eski gelenekler ve Batılı usuller arasındaki bocalamaya bulunan çare genelde orta yol ve ölçülülüktür. Örneğin, Bülent Davran'a göre, görücülük gibi eski evlenme usulleri geçerliliğini kaybettiğinden evlenmek eskiye nazaran çok daha zordur. ${ }^{86}$ Batı'daki gibi çiftlerin evlenmeden birlikte yaşamaları kabul edilemez; fakat kadın-erkek arası 'nezih münasebetler'e de gerici bir tutumla yaklaşmamalıdır. ${ }^{87}$ Modernleşmenin getirdiği sosyal dönüşümlerin yanı sıra, hukuki dönüşümlerin de aileyi etkilediği görülür. ${ }^{88}$ Medeni yasayla evlenme yaşının yükseltilmesi, bu yaştan önce cinsel erginliğe erişen erkeklerin ve özellikle kızların namuslarını kaybetmelerine ve gayri meşru çocukların doğmasına neden olmaktadır. ${ }^{89}$ Toplumdaki hızlı dönüşüm aileyi ve toplumsal hayatı sarsmakta, tehdit etmektedir. Bu tehdit birçok farklı biçimde kendini gösterir: sadakatsizlik, sahte evlilikler ${ }^{90}$, boşanmalar. ${ }^{91}$ Özellikle boşanma, 'denetleyici kuşak' için ciddi bir sorundur. ${ }^{92}$ Dönemin ünlü boşanma avukatlarından biri ile yapılan söyleşiye göre, boşanma oranları artmaktadır. ${ }^{93}$ Bunun nedeni, aile ahlakının bozulması, vicdanların sarsılması, kadınların tahammülsüz 
erkeklerin ise sorumsuz hale gelmeleridir. ${ }^{94}$ Kadınların lükse düşkünlükleri, sorumsuzca harcamalar yapmaları ve isteklerinin sonsuzluğu boşanmaların en önemli nedenleri olarak gösterilmektedir. ${ }^{95}$

Cinselliğin düzenlenmesi, yalnızca hazlar dünyasına karşı kurgusal bir ailenin konumlandırılması bağlamında incelenemez. Doğurganlığın düzenlenmesi yoluyla, cinsellik siyasal projelerin bir parçası haline gelir.

[C]inselliğin ... siyasal işlemlerin, iktisadi müdahalelerin (üremeyi özendirici ya da kısıtlayıcı davranışlar yoluyla), ahlaklı ya da sorumlu kılma amacıyla girişilen ideolojik kampanyaların temasına dönüştüğü de görünür: $\mathrm{Bu}$ durumda cinsellik bir toplumun güç göstergesi olarak değerlendirilir, hem siyasal enerjisini hem de biyolojik gücünü gösterir. ${ }^{96}$

Cinsel terbiyenin nihai amacı, ailenin ve bu ailelerin doğup büyüteceği çocukların sıhhatidir. Çocuk bakımı, doğum öncesinde ve esnasında yapılması gerekenler önceleri de Seksoloji'de yer alır, fakat doğumun ve doğurganlığın düzenlenmesi ancak 1952 yılında doğrudan ele alınmaya başlar. 1952'de Amerika'daki cinsel bilimcilerle kurulan ilişkiler ve 1952 yılının sonunda Abraham Stone'un Türkiye'ye gelmesi bu ilgide rol oynamışa benzemektedir. ${ }^{97}$

Abraham Stone, Aralık 1952'de Seksoloji'nin davetlisi olarak Türkiye'de konferanslar vermiştir. Stone, konuşmalarında dünya nüfusunun hızlı artışından ve kıt kaynakların nüfusu doyurabilmesi için dünyanın birçok yerinde doğurganlığın düzenlendiğinden bahsetmiştir. ${ }^{98}$ Her ne kadar Türkiye gibi nüfus yoğunluğunun az olduğu bir ülkede doğurganlığı önleyici tedbirler gereksiz gibi görünse de, Stone aile planlamasının Türkiye'nin sıhhati ve refahı için gerekli olduğunu söylemiş̧tir. ${ }^{99}$ Stone'un konferansı sonrasında, Seksoloji yazarları Türkiye'de doğum kontrolü ve nüfus planlamasını tartışmaya başlamıştır. Akbeğ, Türkiye'nin fazla nüfusa ihtiyacı olduğunu kabul eder fakat, ${ }^{100}$ doğum kontrolünü yasaklayıcı önlemler yerine doğumu teşvik edici uygulamaları savunur. Her aile 'en az üç çocuk' yapmalıdır, fakat ailelerin bakabileceklerinden çok çocuk yapmaları, maddi ve manevi yönden zayıf bir nüfusun ortaya çıkmasına neden olacaktır. Bu nedenle yeterince çocuk yapmış olan veya tıbben çocuk yapması tehlikeli olan kadınlara önleyici tedbirler öğretilmelidir. ${ }^{101}$ Çok çocuk yapmış kadınlara yönelik bilgilendirme kadını gözeten bir yerden önerilmemektedir. Zira yazarlara göre ‘üç çocuğu' olmayan kadınlara doğum kontrol bilgisi verilmemelidir.

Yüksek çocuk ölümleri de Seksoloji'deki yazılarda ele alınır. Nüfusun yeterince artmıyor olması, yüksek çocuk ölümü oranlarıyla ilişkilendirilir. Kayıhan ve Uraz'a göre, Türkiye toprakları nüfusundan çok daha fazlasını besleyebileceği için doğumu engellemeye gerek yoktur. Fakat doğurganlık yüksek olduğundan doğumun teşvik edilmesi de gerekli bulunmaz. Yapılması gereken çocuk ölümlerini durdurmak ve 'memleketin istikbali' çocukları en iyi biçimde yetiştirmektir. ${ }^{102}$

\section{Sonuc}

Seksoloji dergisi, cinsel terbiye alanında konuşmak için hekimleri hukukçuları ve dönemin önde gelen entelektüellerini 'salahiyetli’ kılmıştır. Fakat bu yetkinin, diğer iktidar bağıntıları içerisinde kadar geçerli olduğu tartışmalıdır. Her ne kadar dergi kendisini, cinsel terbiye alanında herkesçe kabul gören bir yayın olarak tanıtsa da, yayımlandığı dönemde ne gibi tepkilerle karşılaştı̆̆ı, okuyucu kitlesinin kimlerden oluştuğu ve söylemsel etki alanı daha fazla araştırılmaya muhtaçtır.

Cinsellik bilimi, cinselliğe dair içerici bir söylem geliştirmiş olsa da, cinsellik üzerinde topyekûn denetleyici bir rol oynayamamış, ${ }^{103}$ hem Türkiye'de hem de dünyada, cinsellik üzerinde ancak kısmi bir otorite olarak kendini kurabilmiştir. Cinsellik bilimi söylemi her ne kadar cinselliği ayıp olanın sınırlarından çıkarmayı amaçlasa ve kendisini pornografik olandan ayırmaya çalışsa da, bazen pornografiyle aynı muameleyi görmüştür. Kitapları yasaklanmış, yazarları davalara konu olmuş ve ceza almış, ${ }^{104}$ bazı çalışmalar yoğun tepkiyle karşılanmıştır. ${ }^{105}$ Türkiye'de cinsellik biliminin ve cinsel terbiye söyleminin, ne gibi iktidar bağıntılarının içine yerleştiğinin, hangi söylemlerle eklemlendiğinin anlaşılması için nasıl tepkilerle karşılaştığının da araştırılması gerekmektedir.

Türkiye'de Seksoloji dergisinin yayımlanmaya başladığı dönemde, cinselliğin modernleşmenin gündelik hayatta ortaya çıkan beklenmedik ve denetimsiz etkilerini bünyesinde toplayan bir kavram olarak sunulduğunu görürüz. Seksoloji bu etkilerin nasıl denetim altına alınacağı, cinselliğin nasıl terbiye edileceği konusunda rehber olmayı amaçlamaktadır. Bir yandan terbiye yoluyla cinselliği içinde bulunduğu karanlıktan çıkaracağını söylerken, bir yandan da cinselliği sürekli kendi yıkıcılı̆̆ içerisinde tanımlayarak bu etkileri kamçılar.

$\mathrm{Bu}$ yazıda yapmaya çalıştığım çözümlemeyi kısa bir dönemle sınırlı tuttum. Oysa Seksoloji'nin yayımlandığı dönemin hem öncesiyle, hem de sonrasıyla sürekliliklerinin kurulması, cinsel terbiye söyleminin 
farklı söylemlerle nasıl eklemlendiğinin etraflıca tartışılması önemlidir. Böylesi bir tartışma Türkiye'de cinselliğin nasıl kurulduğunun ve toplumsal cinsiyet rejimindeki dönüşümlerin anlaşılması için faydalı olacaktır. 
${ }^{1}$ Heike Bauer, English Literary Sexology: Translations of Inversion, 1860-1930 (Londra: Palgrave Macmillan, 2009$): 3$.

${ }^{2}$ Bauer, English Literary Sexology, 4.

${ }^{3}$ Michelle Foucault, Cinselliğin Taribi (İstanbul: Ayrınt1, 2003): 56.

${ }^{4}$ Foucault, Cinselliğin Taribi, 57.

${ }^{5}$ Foucault, Cinselliğin Taribi, 76.

${ }^{6}$ Foucault, Cinselliğin Taribi, 80.

${ }^{7}$ Foucault, Cinselliğin Taribi, 86.

${ }^{8}$ Foucault, Cinselliğin Taribi, 84-85.

${ }^{9}$ Foucault, Cinselliğin Taribi, 89.

${ }^{10}$ Foucault, Cinselliğin Taribi, 89.

${ }^{11}$ Foucault, Cinselliğin Taribi, 96.

${ }^{12}$ Erik J. Zürcher, Modernleşen Türkiye'nin Taribi. (İstanbul: İletişim, 1995): 304-309.

${ }^{13}$ Deniz Kandiyoti, Cariyeler, Bacılar, Yurttaşlar: Kimlikler ve Toplumsal Dönüşümler. (İstanbul: Metis, 1997): 193.

${ }^{14}$ Serpil Sancar, Türk Modernleşmesinin Cinsiyeti: Erkekler Devlet, Kadınlar Aile Kurar. (İstanbul: İletişim, 2012$): 232$.

${ }^{15}$ Sancar, Türk Modernleşmesinin Cinsiyeti, 233.

${ }^{16}$ Sancar, Türk Modernlessmesinin Cinsiyeti, 234.

${ }^{17}$ Sancar, Türk Modernleşmesinin Cinsiyeti, 235.

${ }^{18}$ Sancar, Türk Modernleşmesinin Cinsiyeti, 259.

${ }^{19}$ Cantek'e göre, denetleyici kuşak doğum tarihleri on dokuzuncu yüzyll sonu ve 20 . yy başına denk düşen, meşruiyetlerini savaşta ve cumhuriyetin kuruluşunda etkin bir rol oynamaktan alan isimlerden oluşur. Peyami Safa, Mithat Cemal Kuntay, Refik Halid Karay, Vedat Nedim Tör, Yusuf Ziya Ortaç ve Selim Sırrı Tarcan bu kuşağın isimleri arasında sayılır. Levent Cantek, Cumburiyetin Büluğ Căğ: Gündelik. Yaşama Dair Tartıs̆malar (1945-1950). (İletişim: İstanbul, 2008). Denetleyici kuşağın halka rehber olma isteği günlük gazetelerinkinden ayrılamaz, zira bu yazarların çoğu günlük gazetelerde yazmaktadır. ${ }^{20}$ Cantek, Cumburiyetin Büluğ Çăğ, 26-27.

${ }^{21}$ Cantek, Cumburiyetin Büluğ Çăğ. İletişim: İstanbul, 29-30. Gündelik yaşamın denetlenemezliği karşısında düzenleyici bir rol oynamak isteyen denetleyici kuşak için, cinselliğin de düzenlenmesi önemli bir meseledir. Bu açıdan bakıldığında, denetleyici kuşağın Peyami Safa gibi önemli bir figürünün Sekesoloji`de yazması ilk anda görüneceği kadar şaşırtıcı değildir.

${ }^{22}$ Cantek, Cumburiyetin Bülŭ Cağ, 92.

${ }^{23}$ Cantek, Cumburiyetin Büluğ Căğ, 83.

${ }^{24}$ Sancar, Türk Modernleşmesinin Cinsiyeti, 258-259.

${ }^{25}$ Sancar, Türk Modernleşmesinin Cinsiyeti, 260.

${ }^{26}$ Sancar, Türk Modernleşmesinin Cinsiyeti, 261.

${ }^{27}$ Sancar, Türk Modernleşmesinin Cinsiyeti,262.

${ }^{28}$ Sancar, Türk Modernleşmesinin Cinsiyeti, 265.

${ }^{29}$ Cantek, Cumburiyetin Büluğ Căğ, 86.

${ }^{30}$ Seksoloji "Beşinci yılımızı bitirirken” 10 no.60 (1954):1.

${ }^{31} 1930$ 'larda ABD'ye taşınan ve yeniden yorumlanan cinsellik bilimi ile Türkiye'de Seksoloji dergisi üzerinden kurulan bağ daha yakından incelenmelidir. 1950ler, Türkiye'de ABD etkisinin birçok alanda hissedilmesi açısından önemlidir. İleride de göstereceğim gibi derginin son yıllarında ABD'de cinsel bilim alanında çalışan hekimlerle kurulan ilişkilerle bu bağ daha da güçlendirilmiştir.

${ }^{32}$ Bauer, English Literary Sexology, 15.

${ }^{33}$ Fahreddin Kerim Gökay, 1949-1957 yılları arasında İstanbul valiliği ve belediye başkanlığını yürütmüştür. Seksolojı̉nin Kasım 1949'da yayımlanan sayısında Gökay yeni görevi dolayisiyla tebrik edilmektedir.

${ }^{34}$ Cantek, Cumburiyetin Büluğ Çăğ, 105-106.

${ }^{35}$ Türkiye'de ilk Milli Olimpiyat Komitesi’ni kuran Tarcan, Tanzimat sonrasında ‘beden terbiyesi ve spor konusunda uzmanlașmıs isimlerden' biridir. Funda Cantek ve Betül Yarar, "Erken cumhuriyet dönemi dergi ve gazetelerinde spor ve kadın (1928-1960)" İletişim Kuram ve Araștırma Dergisi no.29 (2009): 201 218. Beden terbiyesi konusunda 'salahiyet' sahibi bir ismin dergiyi onaylaması önemlidir. Tarcan daha sonra Seksoloji de spor ve genç kalma konularında birkaç yazı yazmışır.

${ }^{36}$ Seksoloji, "İkinci Cildimize Başlarken" 2 no.7(1949): 1.

${ }^{37}$ Foucault, Cinselliğin Taribi, 54.

${ }^{38}$ Harry G.. Cocks, "Saucy stories: pornography, sexology and the marketing of sexual knowledge in Britain, c.1918-70" Social History 29, no.4 (2004): 465484.

${ }^{39}$ Muzaffer Aşkın, “Cinsiyet hakkında sıhhatli ve doğru bir anlayışa sahib olmalıyız” Seksoloji 7 no.40 (1952): 1.

40، 'Seksoloji memleket matbuatında nasıl karşılandı?” Le Mon Clark İste Evlendiniz çev. Muzaffer Aşkın (İstanbul: Seksoloji Yayınları, 1950)

${ }^{41}$ Faruk Akbeğ “Seksoloji dört yaşına girerken” Seksoloji 4, no.37 (1952): 3.

${ }^{42}$ Cinsiyet öğretiminden bahseden yazılarda bu belirsiz geçmişin ne olduğu ele alınmasa da, 37. sayıda başlayan "Türkiye'de cinsiyet meselesi” isimli yazı dizisinde geçmişin sınırları çizilmiştir. Sümerler, Hititler, Orta Asya Türkleri, İslam, Selçuklular ve Osmanlı İmparatorluğu, evlilik adetleri ve çocuk yetiştirme yöntemlerinden bahsederken Türkiye'deki cinsiyet meselesinin geçmişi olarak sunulur.

${ }^{43}$ Seksoloji , "Müsabakamizın neticesi” 2 , no.11 (1950): 32-33.

${ }^{44}$ Sözü geçen yazıda cinsellik hakkında gençleri bilgilendirmemenin boşanmalara, cinsel hastalıklara, suiistimallere ve eşcinselliğe yol açtığı söylenmektedir. Howard Whitman "Çocuklara cinsiyetten nasil bahsetmeli?” Seksoloji 2 no.11 (1950): 43.

${ }^{45}$ Faruk Akbeğ, “Okullarda cinsiyet eğitimi: Maarif şurası üyelerinin dikkatine sunulur” Sekesoloji 7 no.42 (1952): 2-8.

${ }^{46}$ Akbeğ, "Okullarda cinsiyet eğitimi," 53.

${ }^{47}$ Mustafa Şekip Tunç “Cinsî hayatın yükseltilmesi” Seksoloji 2 no.8 (1949):2-3. 
${ }^{48}$ Tunç, “Cinsî hayatın yükseltilmesi," 3.

${ }^{49}$ Peyami Safa “Cinsî öğretim ve cinsî eğitim” Seksoloji 7, no.38 (1952):1.

${ }^{50}$ Sözde Kı̨lar (1923) Safa'nın en çok bilinen romanları arasındadır. Bu romanda Safa mel'un karıları, 'dinini milletini sevmeyen, mahallesine, ailesine isyan eden, ırzını namusunu satan’ sözde kızları anlatır. Fatmagül Berktay, 'Yeni kimlik arayışı, eski cinsel düalizm: Peyami Safa'nın romanlarında toplumsal cinsiyet” Kadnn Araştırmalar Dergisi no. 9 (2006): 77-90. http://www.iudergi.com/tr/index.php/kadin/article/view/337.

${ }^{51}$ Peyami Safa, “Sözde kızlar ve çeşitleri”" Seksoloji, no. 49 (1953): 2.

${ }^{52}$ Akbeğ, "Okullarda cinsiyet eğitimi," 8.

${ }^{53}$ Foucault, Cinselliğin Tarihi, 89.

${ }^{54}$ Selçuk Karçal ve Kayıhan Uraz “Tenasülî hastalıklarla mücadele meselesi” Seksoloji 9, no.53 (1953): 49.

${ }^{55}$ Seyfettin Atalan, "İstanbul zührevi hastaliklarla nasil mücadele ediyor?”, 23.

${ }^{56}$ Cantek, Cumburiyetin Bülŭ Căğ, 87.

${ }^{57}$ Karçal ve Uraz “Tenasülî hastalıklarla mücadele meselesi,” 48.

${ }^{58}$ Selçuk Karçal ve Kayıhan Uraz, “Türkiyede fuhuş meselesi” Seksoloji 9, no.51 (1953): 46.

${ }^{59}$ Seyfettin Atalan “İstanbul zührevi hastalıklarla nasıl mücadele ediyor? Ata Tokgöz ile söyleşi” Seksoloji 9, no.50 (1953): 26.

${ }^{60}$ Faruk Akbeğ, "Fuhuşla mücadele" Seksoloji 2, no. 9 (1949): 20.

${ }^{61}$ Sancar, Türk Modernleşmesinin Cinsiyeti, 268.

${ }^{62}$ Sancar, Türk Modernleşmesinin Cinsiyeti, 270.

${ }^{63}$ Nihat Sami Banarlı “Seni düşüren eller” Seksoloji 5, no.29 (1951): 5.

${ }^{64}$ Akbeğ, "Fuhuşla mücadele," 20.

${ }^{65}$ Sancar, Türk Modernleşmesinin Cinsiyeti, 272.

${ }^{66}$ Seksoloji "IIffet ve bekâret" 6, no.35 (1952): 44-46.

${ }^{67}$ Örnek olarak şu yazılar verilebilir: Kemal Çağlar, "Genç kızlarımızla bir hasbihâl” Seksoloji 7, no.38 (1952):36-40, Faruk Akbeğ, "Bekâretin mana ve değeri” Seksoloji 8, no.39 (1952): 1-6, Burhan Öncel “Kızlarda gebelik” Seksoloji 2, no.10 (1950): 26-29. Kizlik zarı ahlaki bir mesele olarak ele alınsa da, bilimsel bilgi eksikliğinin, kızlık zarına gereğinden fazla önem vererek aile hayatının temellerine zarar vereceği de vurgulanır. Burhan Öncel, "Kızlık zarı ve kadının sosyal hayatındaki önemli rolleri” Seksoloji 2, no.7 (1949): 7

${ }^{68}$ Akbeğ, "Okullarda cinsiyet eğitimi”, 2-3.

${ }^{69}$ Sancar, Türk Modernleşmesinin Cinsiyeti, 263.

${ }^{70}$ Ferit H. Saymen "Sarkıntıllı" Seksoloji 5, no.26 (1951): 1. Seksoloji yazarlarının din ve geleneksel ahlak anlayışıyla ilişkileri birbirlerinde ayrılır. Örneğin Selçuk Karçal ve Kayıhan Uraz, Batılılaşmadan önce halkta taassup ve cehalletten kaynaklanan bir ahlak yüksekliği olduğundan, Batılılaşma ile ahlakın önemsizleştiğinden bahsedeler. Karçal ve Uraz, "Türkiyede fuhuş meselesi," 47.

${ }^{71}$ Saymen, "Sarkintilik," 3.

${ }^{72}$ Sancar, Türk Modernleşmesinin Cinsiyeti, 263.

${ }^{73}$ Seksoloji, "Birkaç söz: Sarkıntılık ve moda" 7, no.42 (1952): kapak.

${ }^{74}$ Faruk Akbeğ, "Sarıyer cinayeti ve sadist psikopatlar”, Seksoloji 8, no.44 (1952):11-15.

${ }^{75}$ Akbeğ'e göre cinayet ve tecavüz adeta bir arada olmak zorundadır, çünkü bir kızın bilinci yerindeyken tecavüze uğraması imkansızdır, ufak bir hareket bile filin icrasina engel olur. Akbeğ, "Sarıyer cinayeti ve sadist psikopatlar," 15.

${ }^{76}$ Kemal Çağlar "Çocuklarınızı cinsi sapıklı̆̆a düşmekten koruyunuz” Seksoloji 5 no.26 (1951): 25-27.

${ }^{77}$ Sadi Irmak “Tenasüli hayat ve izdivaç” Seksoloji 2, no. 10 (1950): 13.

${ }^{78}$ Faruk Akbeğ, "Bekar kadının cinsi hayatı" Seksoloji 8, no.43 (1952): 30.

${ }^{79}$ Akbeğ, "Bekar kadının cinsi hayatı," 31.

${ }^{80}$ Irmak "Tenasüli hayat ve izdivaç,"13.

${ }^{81}$ Foucault, Cinselliğin Taribi, 77.

${ }^{82}$ Kitaplar dergiyle birlikte bedava verilmiştir, fakat kitapçlardan edinmek de mümkündür.

${ }^{83}$ Sancar, Türk Modernleşmesinin Cinsiyeti, 234.

${ }^{84}$ Seksoloji, "Aile mecmuası Seksoloji” 8, no.48 (1953): kapak

${ }^{85} \mathrm{Bu}$ dönemde kadının giderek daha fazla aile içinde temsil edildiğini görüyoruz. Firdevs Gümüşoğlu "Cumhuriyet döneminde ders kitaplarında cinsiyet rolleri (1928-1998)" 75 Y Ilda Kadınlar ve Erkekler, der. Ayşe Berktay Hacımirzaoğlu. (İstanbul: Tarih Vakfi Yayınları, 1998), 102. Bu durum erken cumhuriyet döneminde kadınlara biçilen rollerin 1940’lardaki dönüşümüyle açıklanabilir.

${ }^{86}$ Bülent Davran, "Münevver Türk genci, hata arkadaşını seçerken nasıl zorluklarla karşılaşıyor?” Seksoloji no.25 (1951): 1-2.

${ }^{87}$ Fakat Davran, kadın ve erkek için eşit şartları savunduğunun düşünülmesini istemediğini de ekler. Davran, "Münevver Türk genci,”3.

${ }^{88}$ Ailenin düzenlenmesinde tıbbi bilgi kadar hukuki bilgi de öne çıkar. Bu amaçla, derginin hukuk alanındaki uzmanı Ferit Hakkı Seymen "Evlenme yaşı", "Evlenme hürriyeti”, "Evlilikte eşitlik", "Kanun karşısında kadın ve erkeğin zinası”” gibi yazı dizileri ve makalelerle, İslam hukukuyla karşılaştırmalı olarak yeni yasalarda bu konuların nasıl düzenlendiğine dair bilgi vermektedir. Seymen'in yazılarında ortak nokta, güncel yasaların, toplumun ihtiyaçlarıyla modernleşmenin gerekliliklerini aynı anda bir araya getirdiğinin, ortayı bulduğunun vurgulanması olmuştur.

${ }^{89}$ Ferit Hakk1 Saymen, "Evlenme yaşı" Sekesoloji 2, no.12 (1950): 8-9.

${ }^{90}$ Ferit Hakk1 Saymen, “Evlenme hürriyeti: Cali evlenmeler” Seksoloji 6, no. 35 ,(1952): 6-9.

${ }^{91}$ Toplumsal dönüşümlerin ailenin çözülmesine neden olduğu iddialarına şüpheyle yaklaşanlar da vardır. Şekip Tunç'a göre aile kendisini çağın gereklerine uydurmaya çalışmaktadır, arada hatalara düşmesi doğaldır. Aileyi devam ettiren hayat kanunudur, bu nedenle de ailenin çözülmesi mümkün değildir. Şekip Tunç, "Cinsî olgunluğun evlilikteki kiymeti” Seksoloji 2, no. 11 (1950): 2-3.

${ }^{92}$ Cantek, Cumburiyetin Büluğ Căgr, 83, 93.

${ }^{93}$ Oysa 1953 tarihli Nüfus Hareketleri İstatistiŏğ’nden faydalanan Cantek'e göre, bu dönemde yüksek boşanma oranlarından söz edemeyiz. Levent Cantek, Cumburiyetin Büluğ Çăğ, 83. Karçal ve Uraz da, 1945 yılı istatistiklerinden faydalanarak Türkiye'de boşanma eğiliminin düşük olduğunu söylemektedirler. 
Selçuk Karçal ve Kayıhan Uraz “Türkiye'de cinsiyet meselesi XII: Boşanmalar” Seksoloji 8, no. 47 (1953): 46.

${ }^{94}$ Irfan Emin "Niçin boşanıyorlar? Ata Tokgöz ile söyleşi” Seksoloji 9, no.52 (1953): 12.

${ }^{95}$ Cantek, Cumburiyetin Büluğ Çăg $, 83,93$.

${ }^{96}$ Foucault, Cinselligin Taribi, 107-108.

${ }^{97}$ Aynı yıl içerisinde Hannah ve Abraham Stone'un “Evlilik rehberi”nin de aralarında bulunduğu kitaplardan yararlanarak hazırlanan Doğumu Tanzim (1952) isimli kitap Seksoloji yayınlarından çıkmıştır.

${ }^{98}$ Metin Ergin “Dr. Abraham Stone'a göre 1. Dünya nüfusunun artış1 ve tehlikeleri 2. Geç evlenmenin mahzurları” Seksoloji 8, no. 46 (1953): 21 , Faruk Akbeğ "Dünyada doğumu tanzim cereyanları ve memleketimiz" Seksoloji 8, no. 47 (1953): 1.

${ }^{99}$ Faruk Akbeğ "Dünyada doğumu tanzim cereyanları ve memleketimiz” Seksoloji 8, no. 48: 2.

${ }^{100} 1920$ 'li yıllarda doğurganlığı Özendirici pro-natalist politikalar benimsenir ve kürtaj ırkın bütünlüğünü, sağlı̆̆ını, kamu ahlakını ve ailenin temelini sarsan bir uygulama olarak yasaklanır. 1920'lerin pro-natalist nüfus politikalanı, ancak 1 Nisan 1965 tarihli Nüfus Planlaması Hakkında Kanun ile birlikte yasalar düzeyinde tersine çevrilmiştir. Elif Ekin Akşit “Geç Osmanlı ve Cumhuriyet dönemlerinde nüfus kontrolü yaklaşımları” Toplum ve Bilim no.118 (2010): 187. Fakat 1950lerle birlikte devletin nüfus politikalarının tartışılmaya başlandı̆̆ını görüyoruz.

${ }^{101}$ Akbeğ "Dünyada doğumu tanzim cereyanları ve memleketimiz," 6.

${ }^{102}$ Selçuk Karçal ve Kayıhan Uraz “Türkiye'de çocuk meselesi” Seksoloji 9, no.50: 3.

${ }^{103}$ Janice M. Irvine, Disorders of Desire: Sexuality and Gender in Modern American Sexology. (Philadelphia: Temple University Press, 2005)

${ }^{104}$ Cocks, "Saucy Stories", 465-484.

${ }^{105}$ Irvine, Disorders of Desire, 237. 


\section{Kaynakça}

Akbeğ, Faruk. “Fuhuşla mücadele” Seksoloji 2, no. 9 (1949): 20-23.

. "Seksoloji dört yaşına girerken” Seksoloji 7, no.37 (1952): 1-3.

. “Bekâretin mana ve değeri” Seksoloji 7, no.39 (1952): 1-6.

. “Okullarda cinsiyet eğitimi: Maarif şurası üyelerinin dikkatine sunulur” Seksoloji 7, no.42 (1952): 2-8.

“"Bekar kadının cinsi hayatı" Seksoloji 8, no.43 (1952): 28-31.

"Sarıyer cinayeti ve sadist psikopatlar" Seksoloji 8, no.44 (1952):11-15.

."Dünyada doğumu tanzim cereyanları ve memleketimiz” Seksoloji 8, no. 47 (1953): 1-4.

. "Dünyada doğumu tanzim cereyanları ve memleketimiz” Seksoloji 8, no. 48 (1953): 1-6.

Akşit, Elif Ekin. "Geç Osmanlı ve Cumhuriyet dönemlerinde nüfus kontrolü yaklaşımları” Toplum ve vilim, no.118 (2010): 179-197.

Aşkın, Muzaffer. “Cinsiyet hakkında sıhhatli ve doğru bir anlayışa sahib olmalıyız” Seksoloji 7, no.40 (1952): 1-5.

Atalan, Seyfettin. "İstanbul zührevi hastalıklarla nasıl mücadele ediyor? Ata Tokgöz ile söyleşi” Seksoloji 9, no.50 (1953): 23-27.

Banarlı, Nihat Sami. “Seni düşüren eller” Seksoloji 5, no.29 (1951): 5-7.

Bauer, Heike. English Literary Sexology: Translations of Inversion, 1860-1930 (Londra: Palgrave Macmillan, 2009).

Berktay, Fatmagül. "Yeni kimlik arayışı, eski cinsel düalizm: Peyami Safa'nın romanlarında toplumsal cinsiyet" Kadın Araştırmaları Dergisi, no. 9 (2006): 77-90.

http://www.iudergi.com/tr/index.php/kadin/article/view/337.

Cantek, Funda ve Betül Yarar. "Erken cumhuriyet dönemi dergi ve gazetelerinde spor ve kadın (1928-1960)" İletişim Kuram ve Araştırma Dergisi, no.29 (2009): 201-218.

Cantek, Levent. Cumhuriyetin Büluğ Çă̆ı: Gündelik Yaşama Dair Tartışmalar (1945-1950) (İletişim:İstanbul, 2008).

Cocks, Harry G. "Saucy stories: pornography, sexology and the marketing of sexual knowledge in Britain, c.1918-70" Social History 29, no.4 (2004): 465-484.

Çağlar, Kemal. “Çocuklarınızı cinsi sapıklığa düşmekten koruyunuz” Seksoloji 5, no.26 (1951): $25-27$. “Genç kızlarımızla bir hasbıhâl” Seksoloji 7, no.38 (1952):36-40.

Davran, Bülent. “Münevver Türk genci, hata arkadaşını seçerken nasıl zorluklarla karşılaşıyor?” Seksoloji 5, no.25 (1951): 1-5.

Emin, İrfan. "Niçin boşanıyorlar? Ata Tokgöz ile söyleşi” Seksoloji 9, no.52 (1953): 11-13.

Ergin, Metin. "Dr. Abraham Stone'a göre 1. Dünya nüfusunun artışı ve tehlikeleri 2. Geç evlenmenin mahzurları" Seksoloji 8, no. 46 (1953): 19-22.

Foucault, Michelle. Cinselliğin Tarihi (İstanbul: Ayrıntı, 2003).

Gümüşoğlu, Firdevs. "Cumhuriyet döneminde ders kitaplarında cinsiyet rolleri (1928-1998)" 75 Yılda Kadınlar ve Erkekler der. Ayşe Berktay Hacımirzaoğlu (İstanbul: Tarih Vakfı Yayınları, 1998), 101-128.

Irmak, Sadi. “Tenasüli hayat ve izdivaç” Seksoloji 2, no. 10 (1950): 13-14. 
Irvine, Janice M. Disorders of Desire: Sexuality and Gender in Modern American Sexology (Philadelphia: Temple University Press, 2005).

Kandiyoti, Deniz. Cariyeler, Bacılar, Yurttaşlar: Kimlikler ve Toplumsal Dönüşümler (İstanbul: Metis, 1997).

Karçal, Selçuk ve Kayıhan Uraz “Tenasülî hastalıklarla mücadele meselesi ” Seksoloji 9, no.53 (1953): 48-53. “"Türkiye'de cinsiyet meselesi XII: Boşanmalar” Seksoloji 8, no. 47 (1953): 44-48.

. “Türkiye'de çocuk meselesi” Seksoloji 9, no.50 (1953): 1-5.

."Türkiyede fuhuş meselesi” Seksoloji 9, no.51 (1953): 46-49.

Safa, Peyami .“Cinsî öğretim ve cinsî eğitim” Seksoloji 7, no.38 (1952):1-3.

."Sözde kızlar ve çeşitleri” Seksoloji 9, no. 49 (1953): 2-3.

Sancar, Serpil. Türk Modernleşmesinin Cinsiyeti: Erkekler Devlet, Kadınlar Aile Kurar (İstanbul: İletişim, 2012).

Saymen, Ferit Hakk1."Evlenme yaşı” Seksoloji 2, no.12 (1950): 8-11.

."Sarkıntılık" Seksoloji 5, no.26 (1951): 1-3.

“"Evlenme hürriyeti: Cali evlenmeler” Seksoloji 6, no. 35 (1952): 6-9.

"Seksoloji memleket matbuatında nasıl karşılandı?” Le Mon Clark İște Evlendiniz çev. Muzaffer Așkın (İstanbul: Seksoloji Yayınları, 1950

Seksoloji. “İkinci Cildimize Başlarken” 2, no.7 (1949): 1-2.

“"Müsabakamızın neticesi” 2, no.11 (1950): 32-35.

. "İffet ve bekâret" 6, no.35 (1952): 44-46.

. "Birkaç söz: Sarkıntılık ve moda" 7, no.42 (1952): kapak.

“"Aile mecmuası Seksoloji” 8, no.48 (1953): kapak

."Beşinci y1lımızı bitirirken” 10, no.60 (1954): 1-2.

Öncel, Burhan. "Kızlık zarı ve kadının sosyal hayatındaki önemli rolleri” Seksoloji 2, no.7 (1949): 7-11.

“"Kizlarda gebelik” Seksoloji 2, no.10 (1950): 26-29.

Tunç, Mustafa Şekip. “Cinsî hayatın yükseltilmesi” Seksoloji 2, no.8 (1949): 2-4.

“Cinsî olgunluğun evlilikteki kıymeti” Seksoloji 2, no. 11 (1950): 1-3.

Whitman, Howard. “Çocuklara cinsiyetten nasıl bahsetmeli?” Seksoloji 2, no.11 (1950): 43-45. 